\title{
Evaluation of Flaws in BTSP Containment Vessel Materials
}

\author{
W. L. Daugherty \\ Savannah River National Laboratory \\ Materials Science \& Technology
}

Publication Date: July 2009

\section{Savannah River Nuclear Solutions \\ Savannah River Site}

Aiken, SC 29808

This document was prepared in conjunction with work accomplished under

Contract No. DE-AC09-08SR22470 with the U.S. Department of Energy. 


\section{DISCLAIMER}

This work was prepared under an agreement with and funded by the U.S. Government. Neither the U. S. Government or its employees, nor any of its contractors, subcontractors or their employees, makes any express or implied: 1 . warranty or assumes any legal liability for the accuracy, completeness, or for the use or results of such use of any information, product, or process disclosed; or 2. representation that such use or results of such use would not infringe privately owned rights; or 3. endorsement or recommendation of any specifically identified commercial product, process, or service. Any views and opinions of authors expressed in this work do not necessarily state or reflect those of the United States Government, or its contractors, or subcontractors. 
Evaluation of Flaws in BTSP Containment Vessel Materials (U)

APPROVALS: 


\section{Revision Log}

$\begin{array}{llll}\text { Document No. } & \text { SRNL-STI-2009-00444 Rev. No. } 0\end{array}$

\section{Document Title Evaluation of Flaws in BTSP Containment Vessel Materials}

Rev. \# Page \# Description of Revision Date

$\begin{array}{lll}0 & \text { all Original document }\end{array}$ 


\section{Summary}

Savannah River National Laboratory designed for the Department of Energy (DOE) a new radioactive shipping packaging for transporting bulk quantities of tritium, the Bulk Tritium Shipping Package (BTSP) as a replacement for a package designed in the early 1970s. In the course of prototype package fabrication the protective cap from four containment vessels failed helium leak testing performed in accordance with ANSI N14.5, Radioactive Materials-Leak Tests on Packages for Shipment. Although these four caps were weld-repaired and subsequently found acceptable, two of the caps were provided to Materials Science \& Technology (MS\&T) and Instrumentation \& Equipment Systems (I\&ES) for non-destructive and destructive examination to identify the cause of the observed behavior. This report documents the results of that examination.

A large concentration of stringers (elongated inclusions) with an orientation parallel to the axis of the bar stock was found within the type 304L stainless steel base material of the protective caps. These generally appear consistent with manganese sulfide stringers, which are commonly found in steels to some extent. In addition, some stringers were found that included aluminum / titanium / calcium compounds. A number of stringers of both types (manganese sulfide and aluminum / titanium / calcium compounds) were long enough to extend through the full thickness of the cap top surface. The aluminum / titanium / calcium stringers tend to be cracked / discontinuous, and provided a leak path through the material.

\section{Background}

The BTSP consists of two primary assemblies, an outer overpack assembly and an inner containment vessel assembly (CV). The CV is designed to hold tritium bearing containers and prevent leakage of tritium under normal and accident conditions of transport. The CV assembly is fabricated from type 304L stainless steel and is 37-1/2 inches high by 14 inches in outside diameter. The assembly has three primary components, the $\mathrm{CV}$ body, the $\mathrm{CV}$ lid and the $\mathrm{CV}$ protective cap.

The CV lid, body, a metallic C-ring seal and the bellows valve comprise the primary containment boundary for the contents. A secondary containment boundary is formed over the bellows valve by the CV protective cap. The cap, designed to protect the Swagelok valve and the quick-connect leak-test fitting, is located in the center of the CV lid. It also incorporates a metallic C-ring similar to, but smaller than, the seal in the primary CV flange closure. The cap is approximately 4 inches in diameter by 2 inches high. Figure 1 illustrates the protective cap installed on the CV lid.

The CV protective cap is designed to retain tritium to the same criteria as the primary containment boundary of the package in the event of concurrent valve and product container failures. The caps were fabricated from ASME SA-479 304L bar as specified by Section II, Part D, of the ASME Boiler \& Pressure Vessel Code.

The material for the caps was electric furnace melted and argon oxygen decarburization (AOD) refined [1]. The cap design is per ASME B\&PV code Section III, Division 1, Subsection NB. Material per NB-2540 requires bar stock to be examined by radiographic, ultrasonic and liquid 
penetrant methods. Evaluation by these methods found no indications as specified by the acceptance standards during pre-fabrication material inspections.

In addition to the bar stock examinations, the fabricated protective caps were subjected to, and passed, a hydrostatic test with test pressure of 750 psi. The caps were held at this pressure for 5 minutes. No leakage was found. Following the hydro-test the caps were thoroughly dried prior to helium leak testing. At this point, four of ten $\mathrm{CV}$ protective caps failed the helium leak test due to material flaws in the base material. Testing was being performed in accordance with ANSI N14.5, Radioactive Materials-Leak Tests on Packages for Shipment.

After eliminating other possible sources of leakage, it was concluded that leakage was occurring through the base metal on the top of the caps. The protective caps were pressurized with helium to approximately 90 psi. A bubble leak test solution was applied to the top of the protective caps. With the aid of a magnifying glass a very small stream of bubbles could be seen at leak locations. Caps 3, 5, 9, and 10 leaked as follows.

- $\quad$ Cap 3 had one place that leaked in the cap top

- $\quad$ Cap 5 had five places that leaked in the cap top

- $\quad$ Cap 9 had four places that leaked in the cap top

- $\quad$ Cap 10 had three places that leaked in the cap top

Weld repairs were made where leaks had been identified. A small weld bead was made over the leak and the weld ground flush and polished. All of the protective caps passed the post weldrepair leak test.

\section{Destructive Examination of Leak Sites}

Two of the weld-repaired caps (caps 5 and 9, Figures 2 and 3) were subjected to non-destructive and destructive examination to determine the nature of the leaks. Both were initially leak tested again by the SRNL IE\&S High Pressure Laboratory to verify the effectiveness of the weld repairs. Figure 4 illustrates a cluster of bubbles that was detected from a leak on cap 9 [2]. No further leaks were noted on cap 5.

The new leak in cap 9 was identified after 10 minutes following pressurizing the cap to 90 psig of helium. The protective cap was held at 90 psig helium for 4 hours to see if other indications would appear over time. No other leakage was found. The inside and outside of the cap 9 top surface were examined optically and in the scanning electron microscope (SEM) at this new leak location. The results are shown in Figures $5-8$.

Initial post test examination of the caps under magnification suggested that the source of the leaks may have been from through wall cracking of the caps. Examples of early inspection of the outside of the cap are shown in Figure 5. The surface finish of the cap surface is approximately 75 micro-inch. The upper two arrows approximate the leak location indicated in Figure 5. Further examination of the cap revealed that the apparent cracks were only superficial and not through-thickness cracks.

On the inside surface, opposite the repair welds, a faint heat tint was visible (Figures 2 and 3 ). The top portion of cap 9 was cut off to provide better access to examine the heat tinted areas for 
evidence of the leak sites. Using this as an indication of the original leak locations, the inside surface was examined at each of these locations in the scanning electron microscope. A number of inclusions were found and analyzed using energy dispersive x-ray spectroscopy. They typically contained silicon, manganese sulfide, and aluminum / titanium / calcium compounds. Cracks were observed in some of these inclusions, suggestive of a potential leak path. These locations are shown in Figure 9. Composition results from the spectroscopy are shown in Table 1. The base metal was also examined using energy dispersive $\mathrm{x}$-ray spectroscopy at several locations near the inclusions. On average, the composition at these locations was consistent with the requirements for Type 304L stainless steel, with the exception that the manganese is slightly elevated ( $2.2 \mathrm{wt} \%$ vs $2 \mathrm{wt} \%$ max allowed).

Two leak locations in cap 9 were further sectioned to examine the leak path through the cap cross section. These included the repaired leak identified as "A" in Figure 2, and the new leak. Leak path "A" is shown in Figures 10 and 11. The cross section pictured is the full $\sim 1 / 8$-inch thickness of the top of the cap. The leakage path was exposed sequentially by grinding approximately $0.002-0.015$ inch of material at a time. The weld bead applied to seal the leak path is clearly visible.

In Figures 10 (f) and 13 (d), the leak path is typically up to 0.002 inch wide (Figures 14 and 15). However, portions of the leak path are visible in Figures $10(\mathrm{~d}-\mathrm{f})$, giving this leak path a width perpendicular to the viewing plane of at least 0.010 inch. The leak path is not an open void, but contains a series of inclusions. These are similar in composition to those seen from the surface mostly aluminum / titanium / calcium compounds. Compositional details are given in Table 2. Note also in Figures 10 and 11 the large concentration of stringers throughout the material. Many of these extend for a significant distance, up to or beyond the nominal $1 / 8$ inch thickness of the cap. Most of these individual stringers appear consistent with manganese sulfide, which is often observed in this type of steel. They are largely crack-free and are not likely to cause leakage. However, their length and concentration are symptomatic of the high degree of impurities that did lead to the leak paths.

The top of cap number 5 was etched to reveal five repair weld locations (Figure 16). Subsequently, a total of 0.010 inch was machined from the top, and it was re-etched. With this minimal material removal, the top was re-etched and 2 of the 5 repair welds were no longer visible (i.e. they were less than 0.010 inch deep). After a vacuum bake to remove cutting oil and other liquid contaminants, a number of leaks were identified in this cap using the method described above (Figure 17). Somewhat surprisingly, none of these locations correspond to the 2 repair weld locations that were machined away. This indicates there are numerous defects throughout the material, with some stopping just short of the original machined surface. It is possible that the machining operation smeared over the previous leak paths just enough to preclude them from leaking at a noticeable rate.

\section{CONCLUSIONS}

Two protective caps fabricated from SA-479 304L bar stock material for the Bulk Tritium Shipping Package were destructively examined to determine the cause of failed helium testing. Stringers were observed throughout the material, at a high concentration and of a length not 
typically seen in this type material. Some of the stringers were of a composition other than the manganese sulfide typically seen in this material. These stringers contained other impurities, and contained a number of cracks throughout, providing a leak path through the base material.

\section{REFERENCES}

1. "BTSP cap material info", electronic mail message from Mike Trosen (Major Tool and Machine, Inc) to Paul Blanton (SRNL), August 4, 2009

2. “PSN-09 Leak Indication", electronic mail message from Donald Trapp (SRNL) to Paul Blanton (SRNL) and William Daugherty (SRNL), June 2, 2009 
Table 1. Composition for inclusions observed at typical locations on the surface of cap 9. (Oxygen and carbon have been excluded from these results)

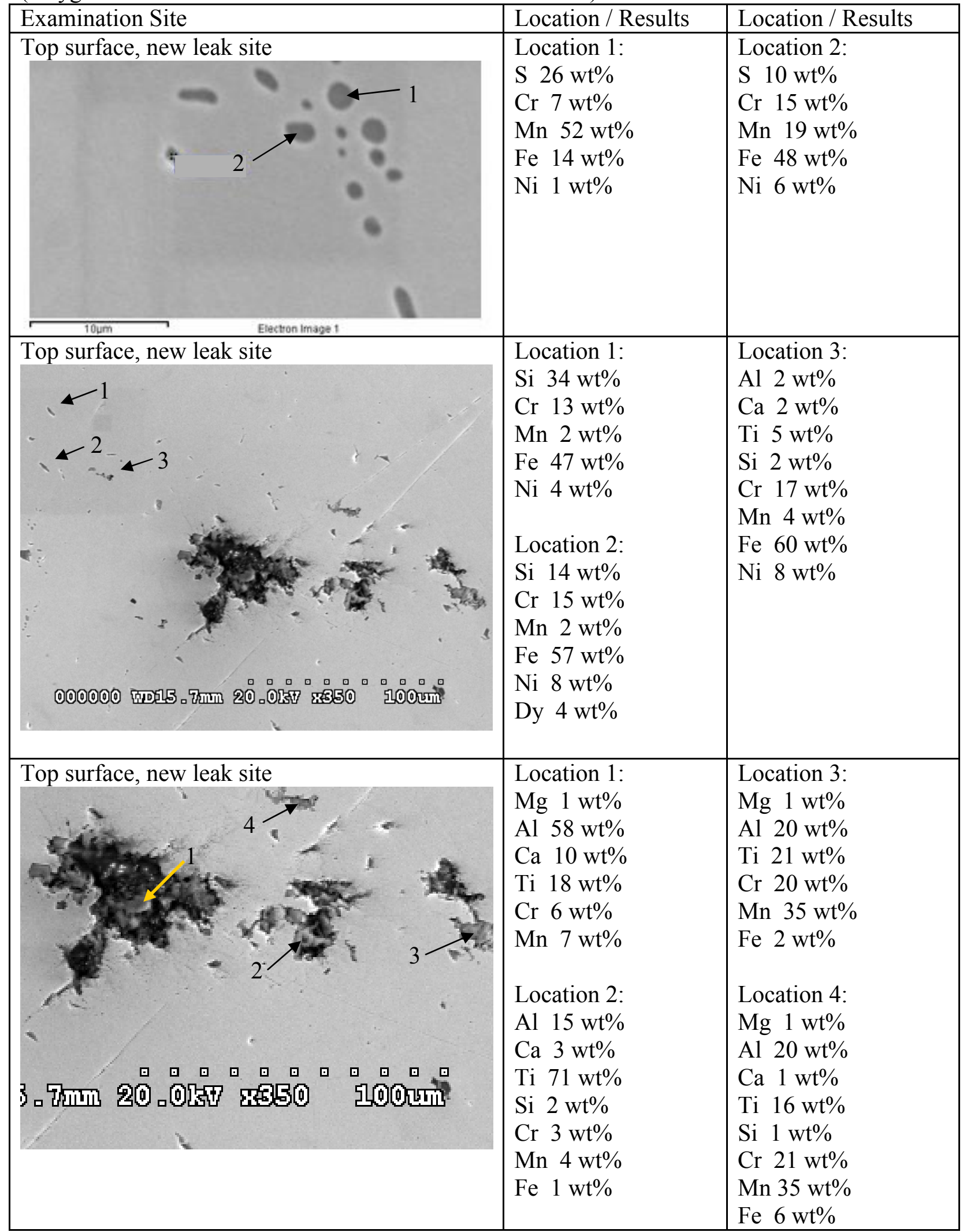


Table 1. (continued)

\begin{tabular}{|c|c|c|}
\hline Bottom surface, weld-repaired leak site 1 & $\begin{array}{l}\text { Location } 1: \\
\mathrm{Al} \quad 6 \mathrm{wt} \% \\
\mathrm{Ti} \quad 6 \mathrm{wt}^{0} \% \\
\mathrm{Cr} \quad 22 \mathrm{wt} \% \\
\mathrm{Mn} \quad 11 \mathrm{wt} \% \\
\mathrm{Fe} \quad 55 \mathrm{wt} \%\end{array}$ & $\begin{array}{l}\text { Location } 2: \\
\text { Al } 22 \mathrm{wt} \% \\
\text { Si } 6 \mathrm{wt}^{0} \% \\
\mathrm{Ti} \quad 10 \mathrm{wt} \% \\
\mathrm{Cr} 23 \mathrm{wt} \% \\
\mathrm{Mn} 29 \mathrm{wt} \% \\
\mathrm{Fe} \quad 10 \mathrm{wt} \%\end{array}$ \\
\hline $\begin{array}{lll}60 \mu \mathrm{m} & \text { Electron Image } 1\end{array}$ & & \\
\hline Bottom surface, weld-repaired leak site 2 & 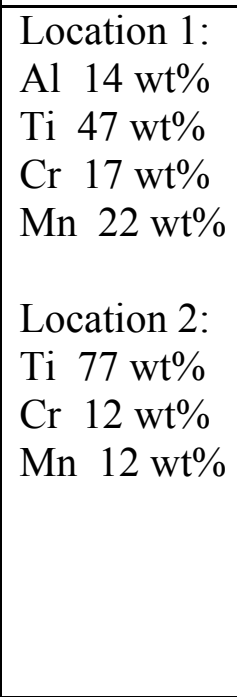 & $\begin{array}{l}\text { Location } 3: \\
\text { Al } 8 \mathrm{wt} \% \\
\mathrm{Ti} \quad 16 \mathrm{wt} \% \\
\mathrm{Cr} \quad 18 \mathrm{wt} \% \\
\mathrm{Mn} \quad 11 \mathrm{wt} \% \\
\mathrm{Fe} \quad 47 \mathrm{wt} \%\end{array}$ \\
\hline Bottom surface, weld-repaired leak site 3 & $\begin{array}{l}\text { Location 1: } \\
\text { Al } 18 \mathrm{wt} \% \\
\text { Si } 2 \mathrm{wt} \% \\
\text { Ca } 4 \mathrm{wt} \% \\
\text { Ti } 45 \mathrm{wt} \% \\
\text { Cr } 9 \mathrm{wt} \% \\
\text { Mn } 9 \mathrm{wt} \% \\
\text { Fe } 13 \mathrm{wt} \%\end{array}$ & $\begin{array}{l}\text { Location 2: } \\
\text { Al } 7 \mathrm{wt} \% \\
\text { Si } 4 \mathrm{wt} \% \\
\text { Ca } 2 \mathrm{wt} \% \\
\text { Ti } 41 \mathrm{wt} \% \\
\text { Cr } 10 \mathrm{wt} \% \\
\text { Fe } 14 \mathrm{wt} \%\end{array}$ \\
\hline$\Longrightarrow$ Election Image 1 & & \\
\hline
\end{tabular}


Table 2. Composition data for inclusions observed along two of the leak paths in cap 9. (Oxygen and carbon have been excluded from these results)

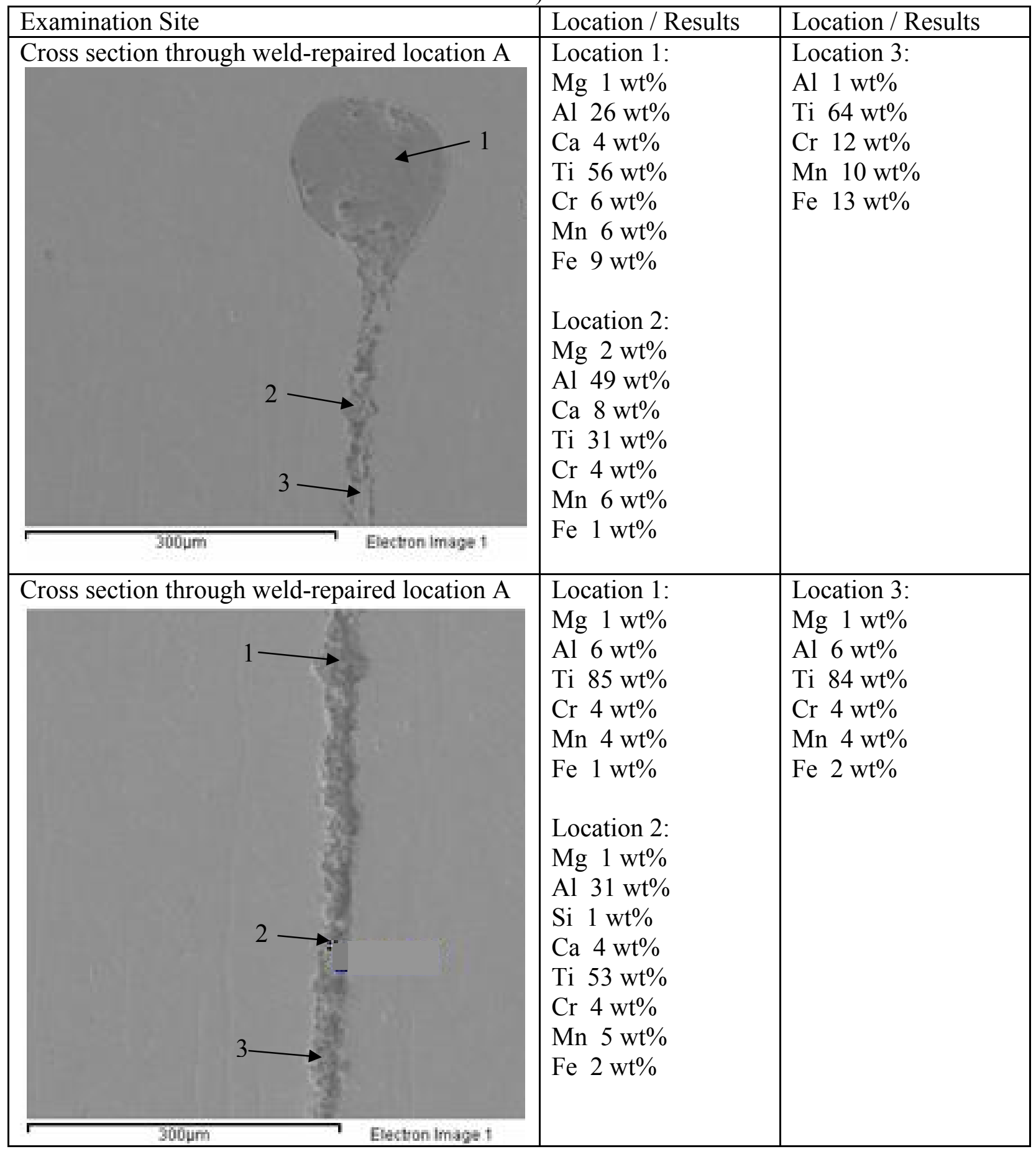


Table 2 (continued)

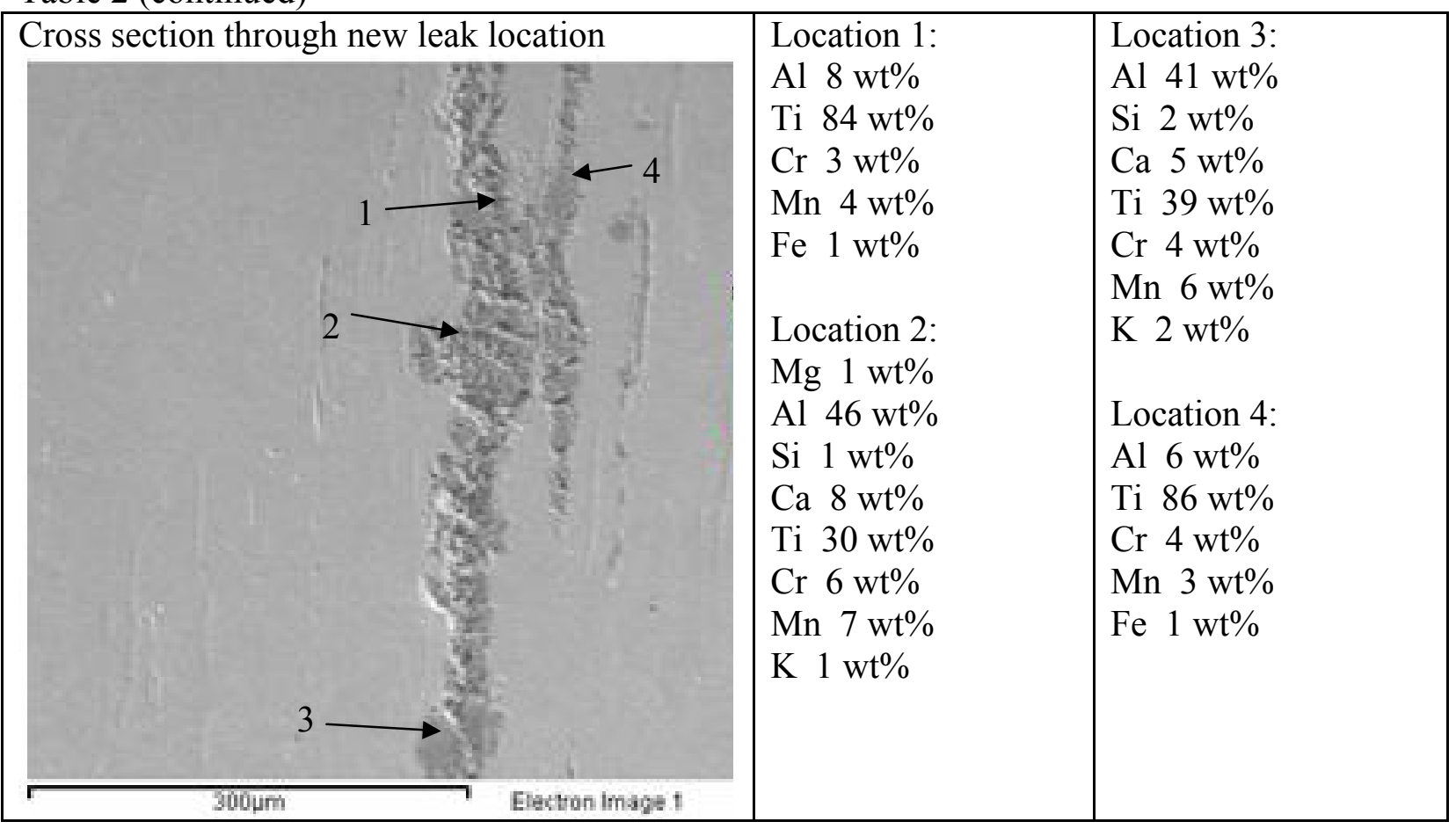




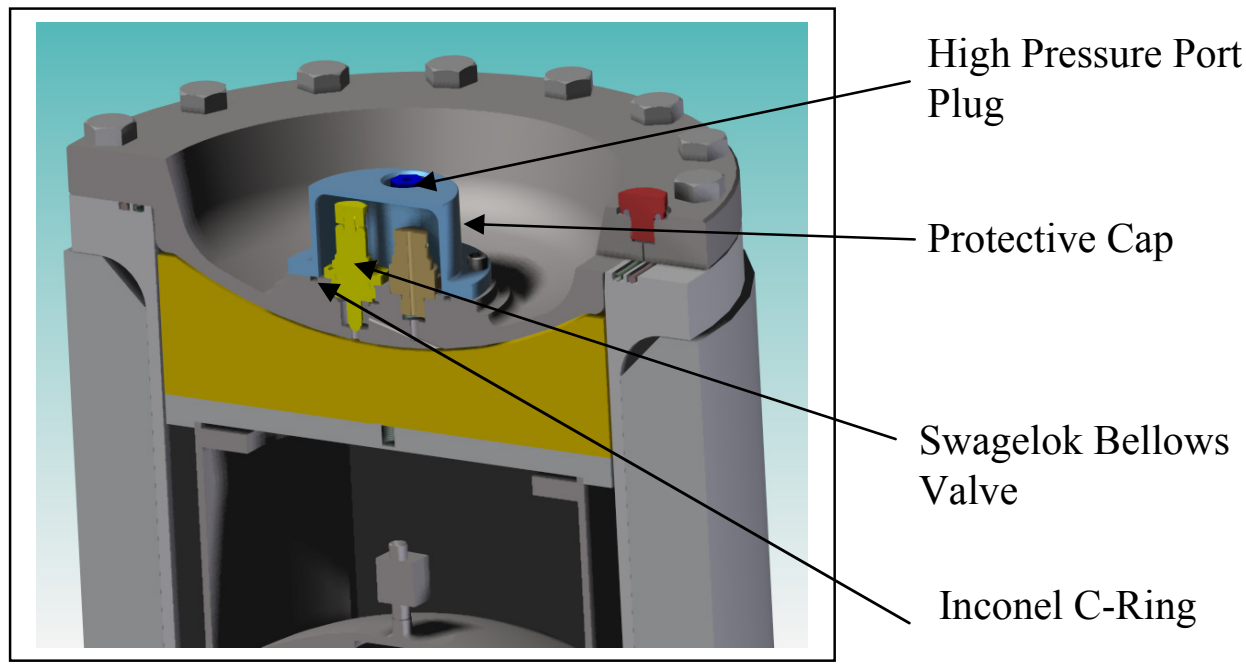

Figure 1. Cross Section of the BTSP Containment Vessel and Protective Cap
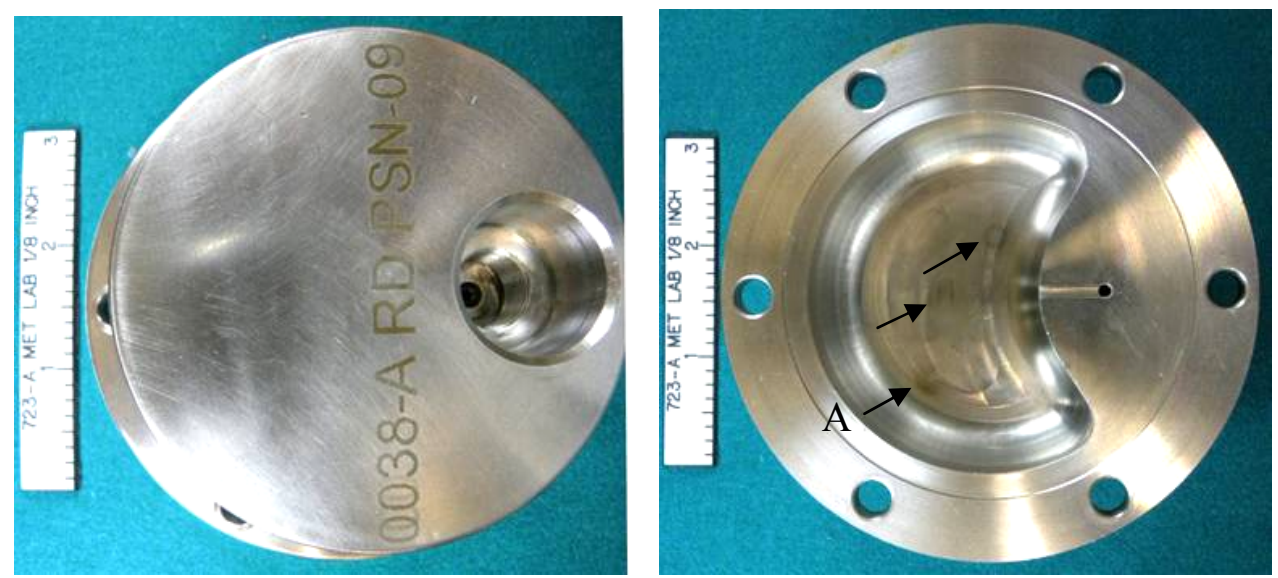

Figure 2. Cap 9, as-received for examination. The welds are not visible in the as ground condition. Note the heat tint on the underside (arrows) from 3 of the 4 repair welds. The leak location labeled "A" was subsequently sectioned.
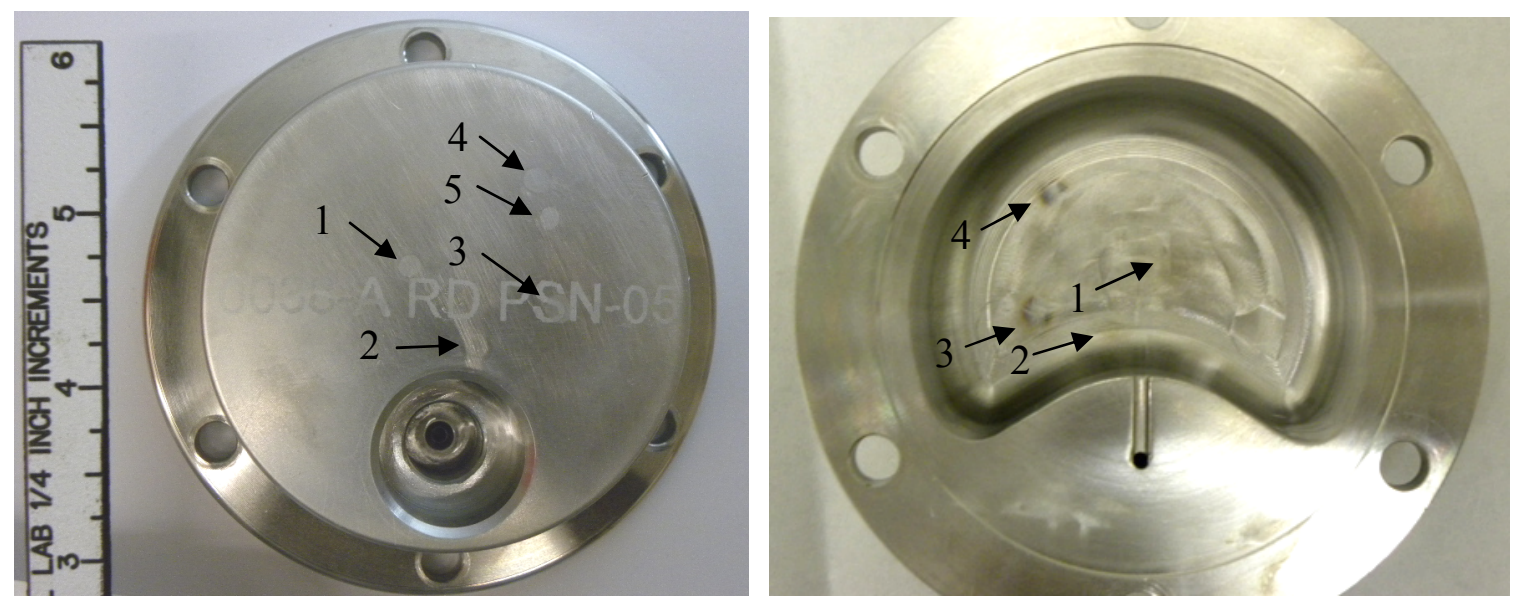

Figure 3. Cap 5, after the top was etched to reveal five repair welds (arrows). Note the heat tint on the underside is visible from 4 of the repair welds. 


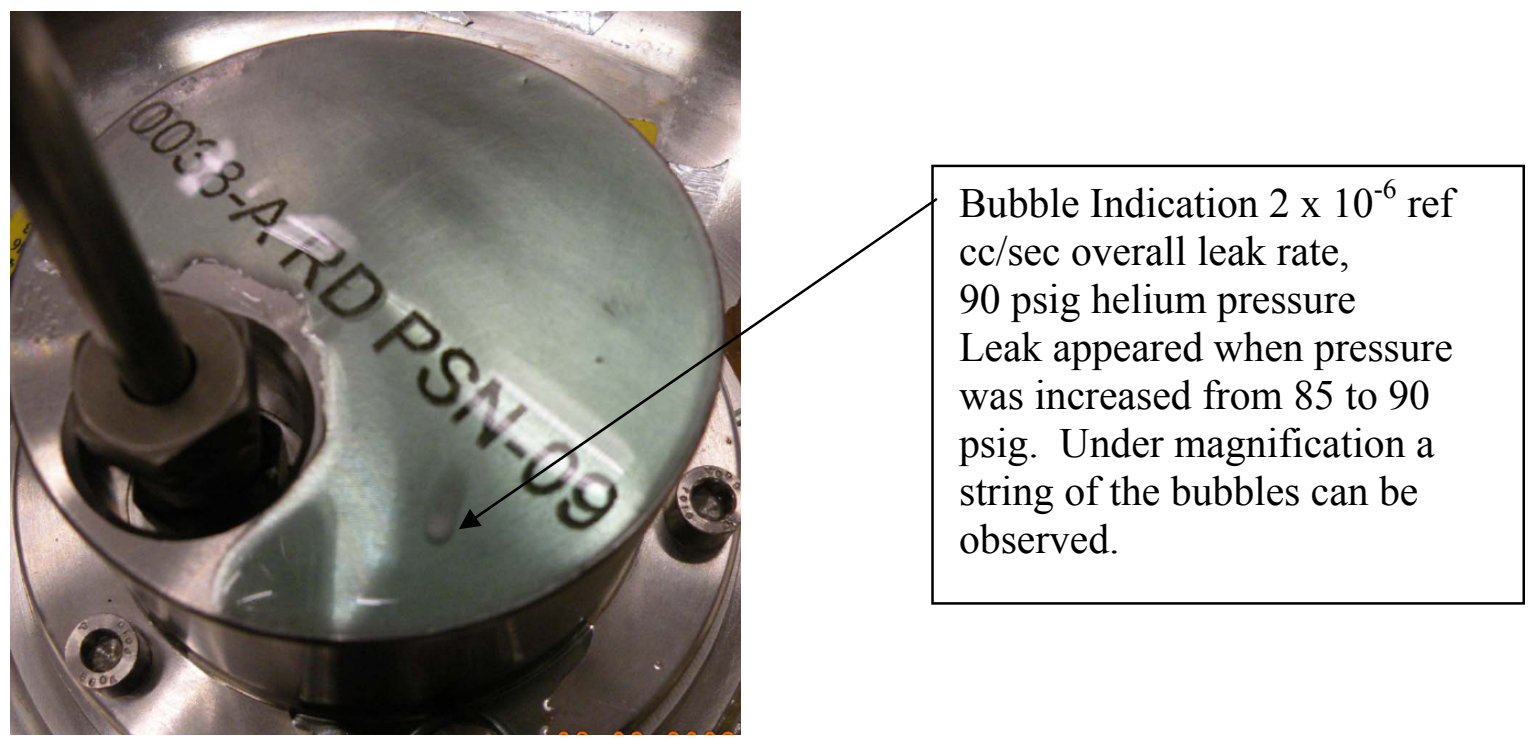

Figure 4. Cap 9 during leak testing. The cloud of bubbles originated from a leak location that was not repaired originally.

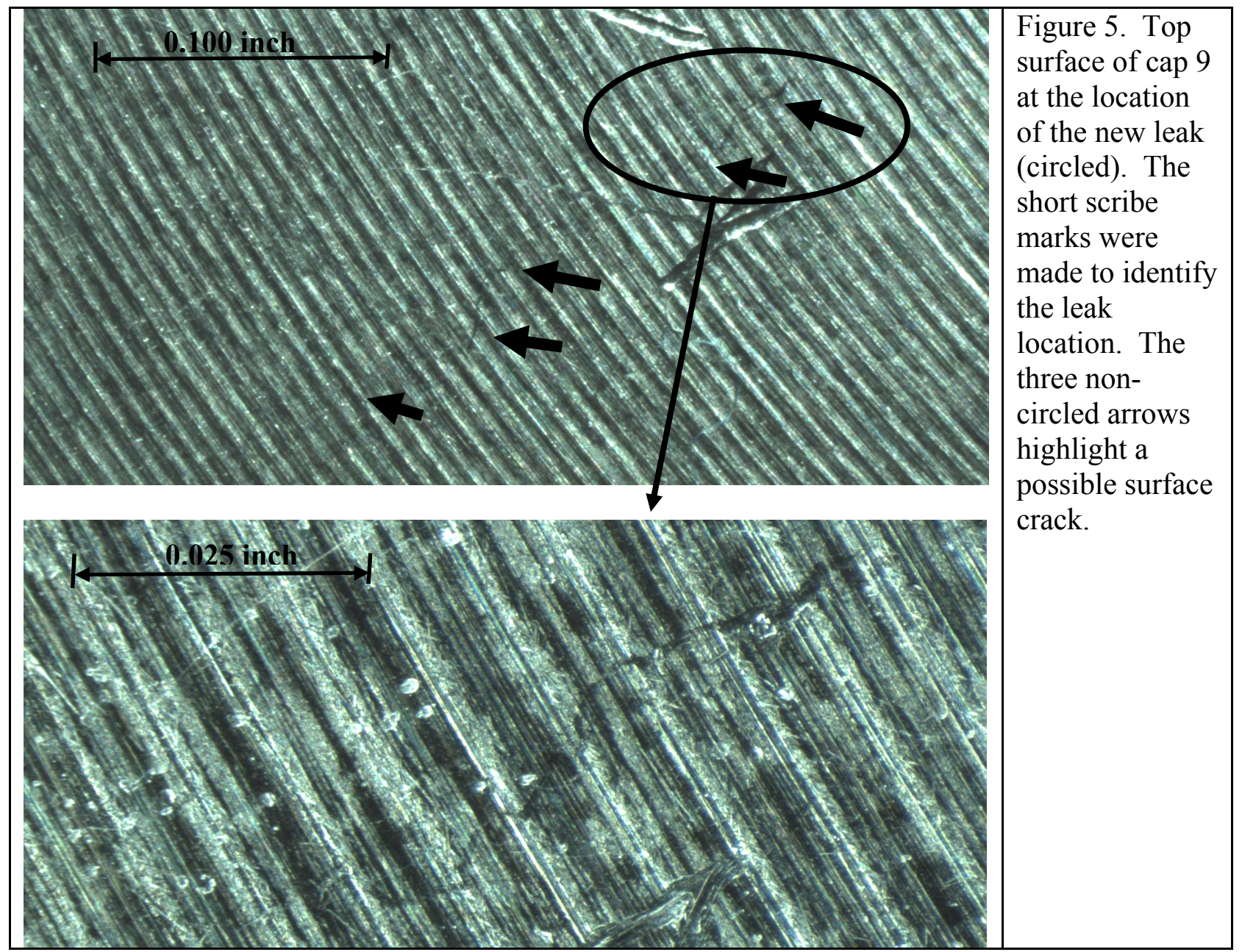




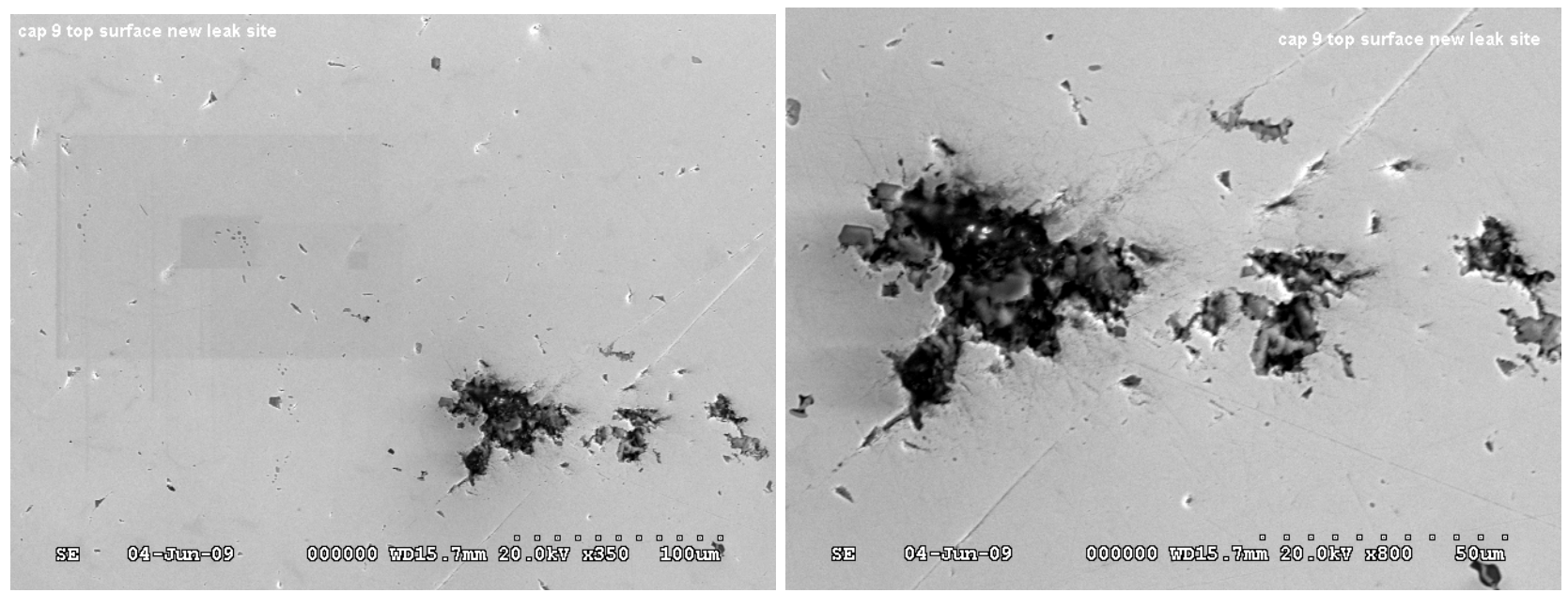

Figure 6. SEM image of cap 9 top surface (after polishing), at the new leak location.
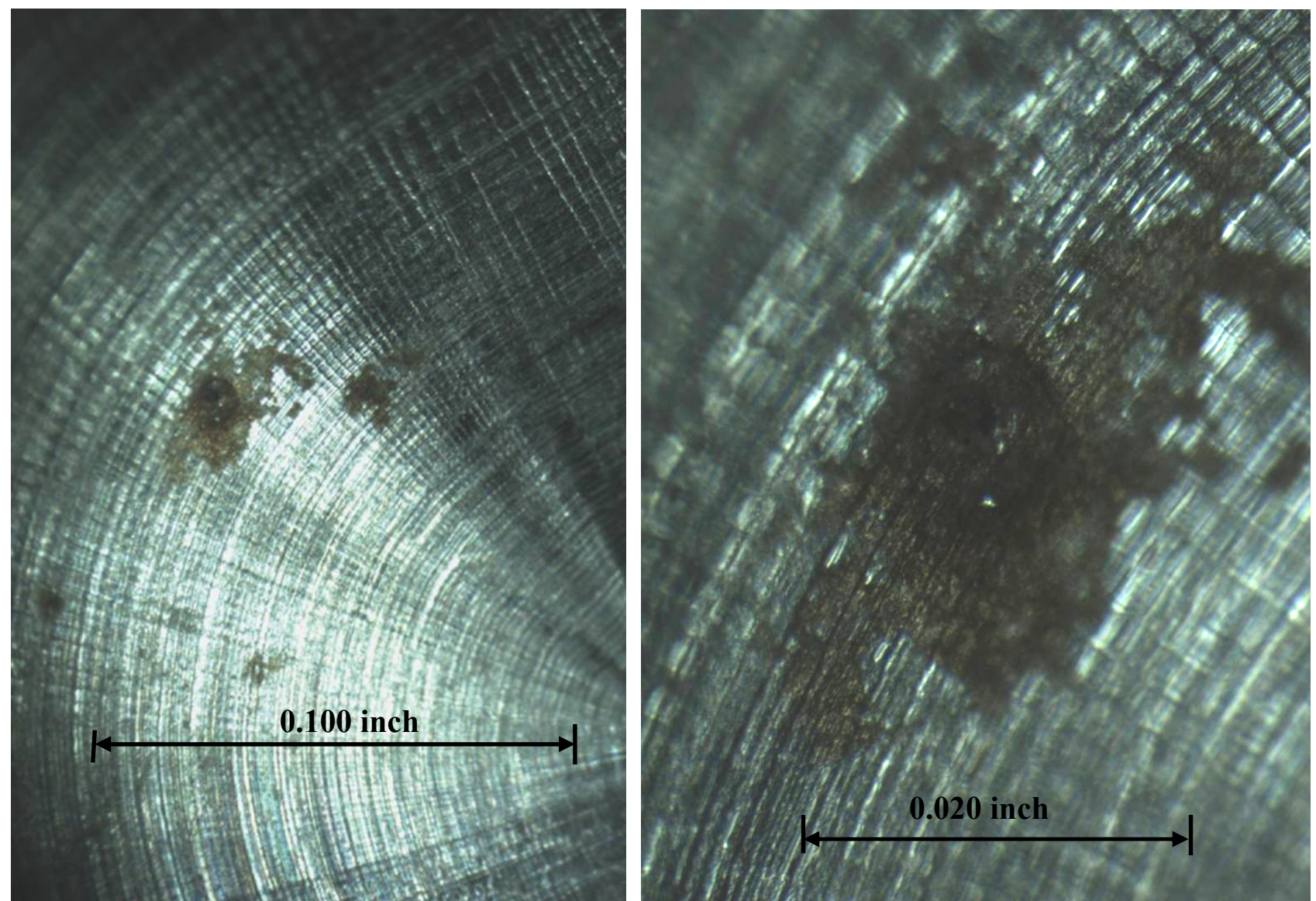

Figure 7. Underside of cap 9, at the location of the new leak. 


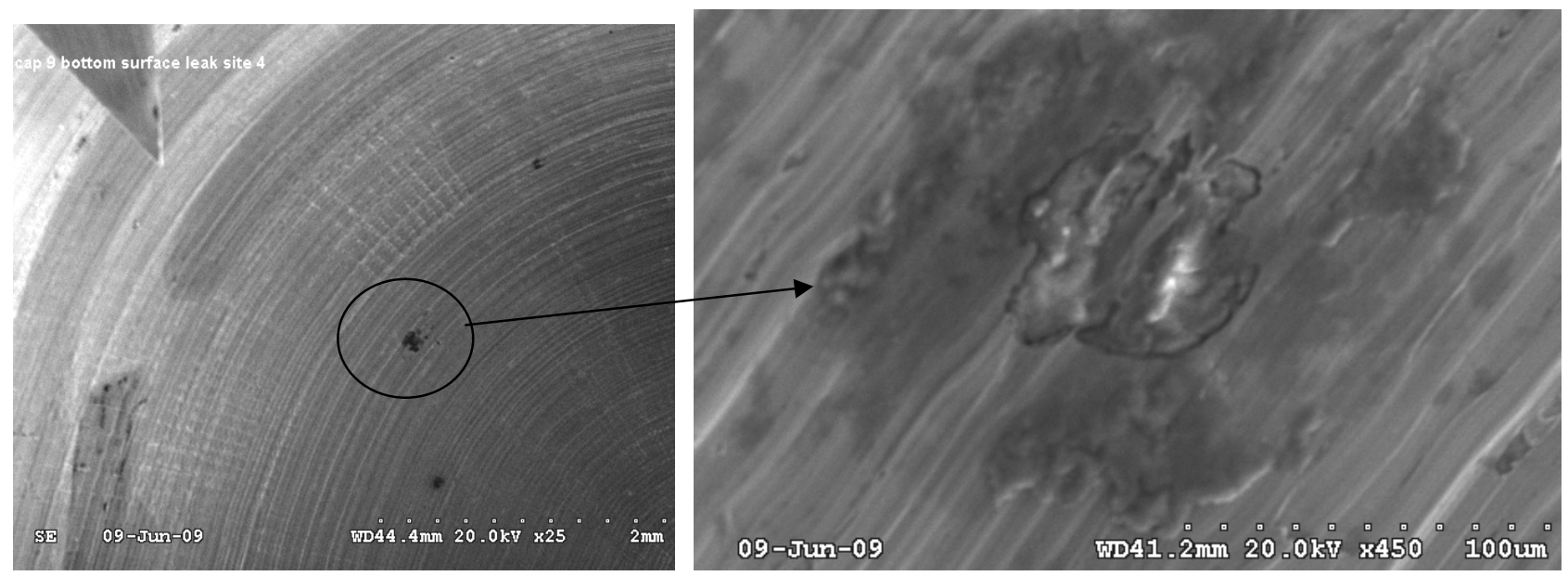

Figure 8. SEM image of cap 9 underside, at the new leak location.
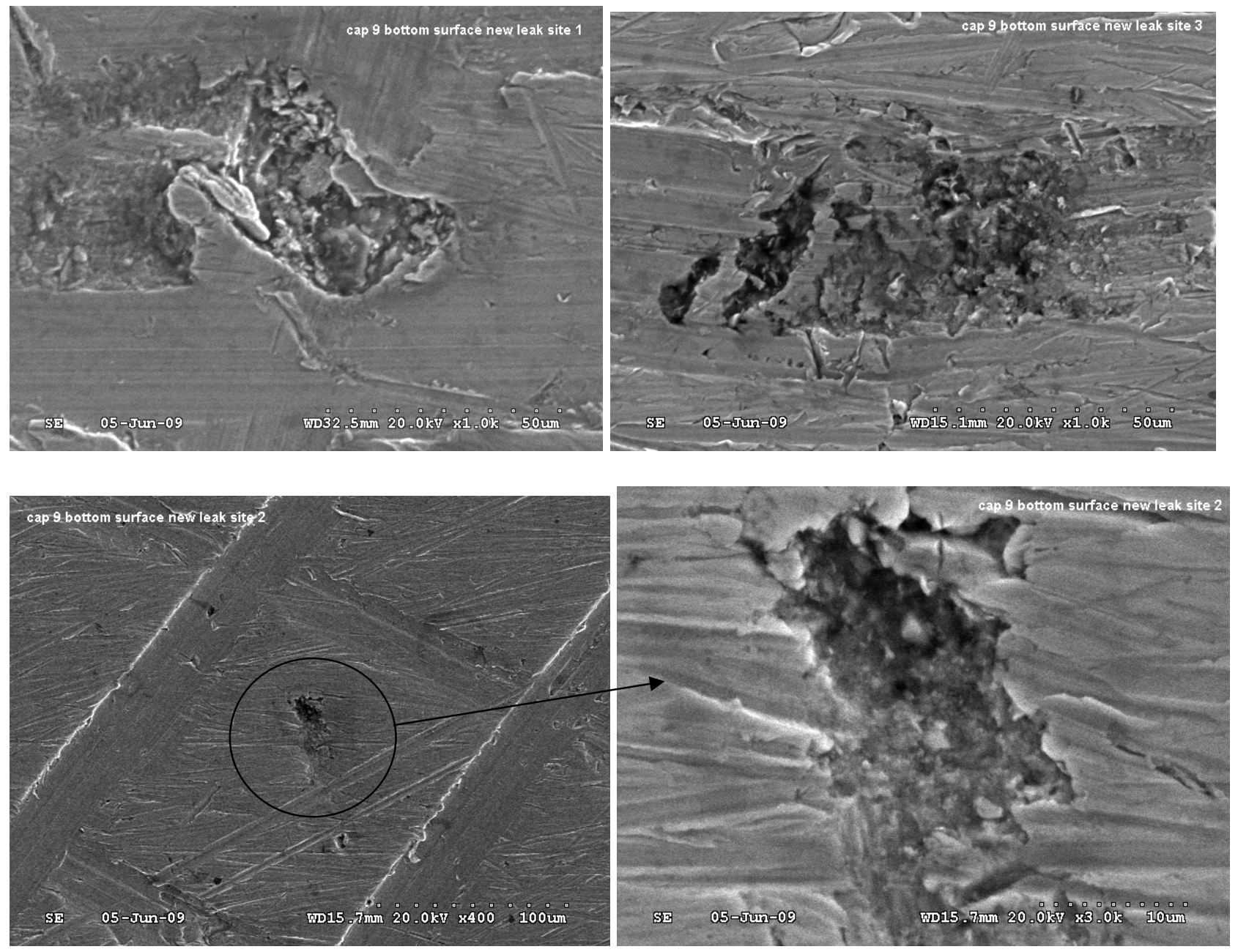

Figure 9. SEM micrograph of the inside surface of cap 9, at the three repaired leak locations. 


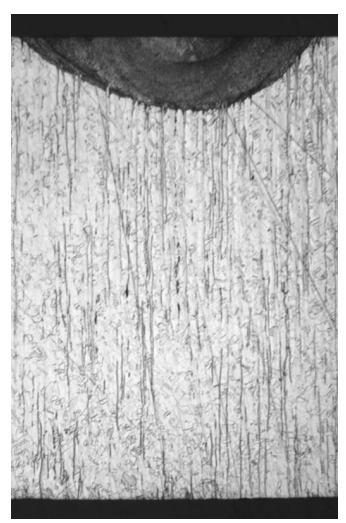

(a)

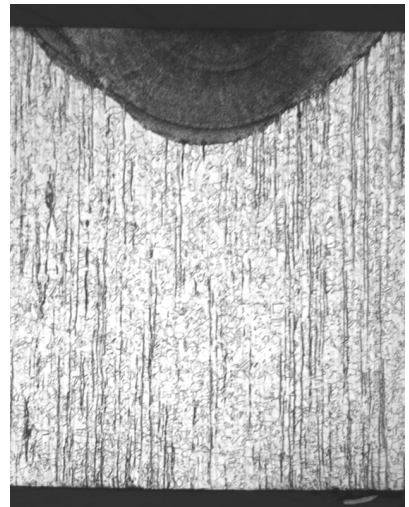

(b) 0.015 inch deeper than (a)

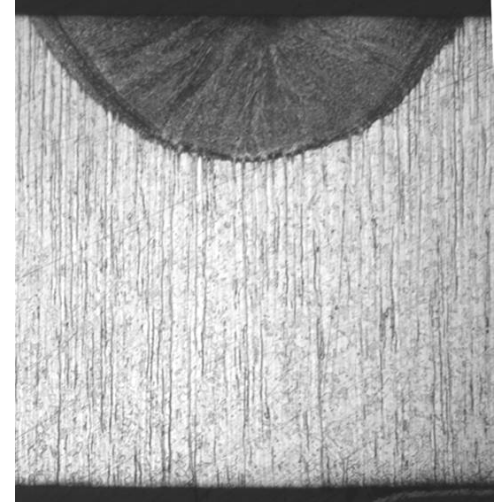

(c) 0.002 inch deeper than (b)

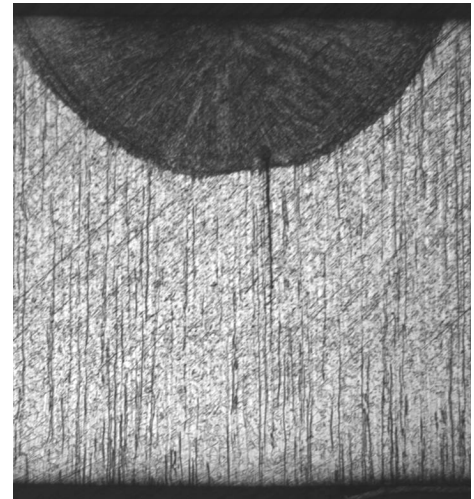

(d) 0.009 inch deeper than (c)

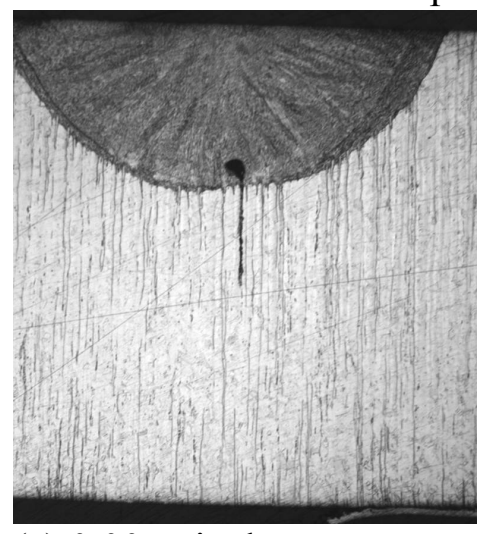

(e) 0.0075 inch deeper than (d)

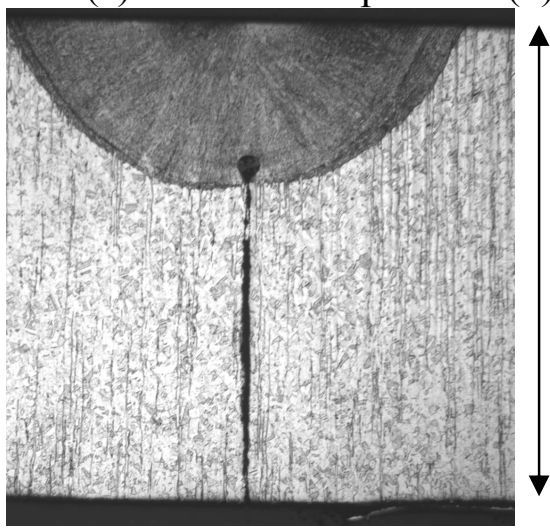

(f) 0.002 inch deeper than (e)

0.127 inch

Figure 10. Series of metallographic cross sections through weld-repaired location "A" in cap 9. Section thickness $=0.127$ inch. 

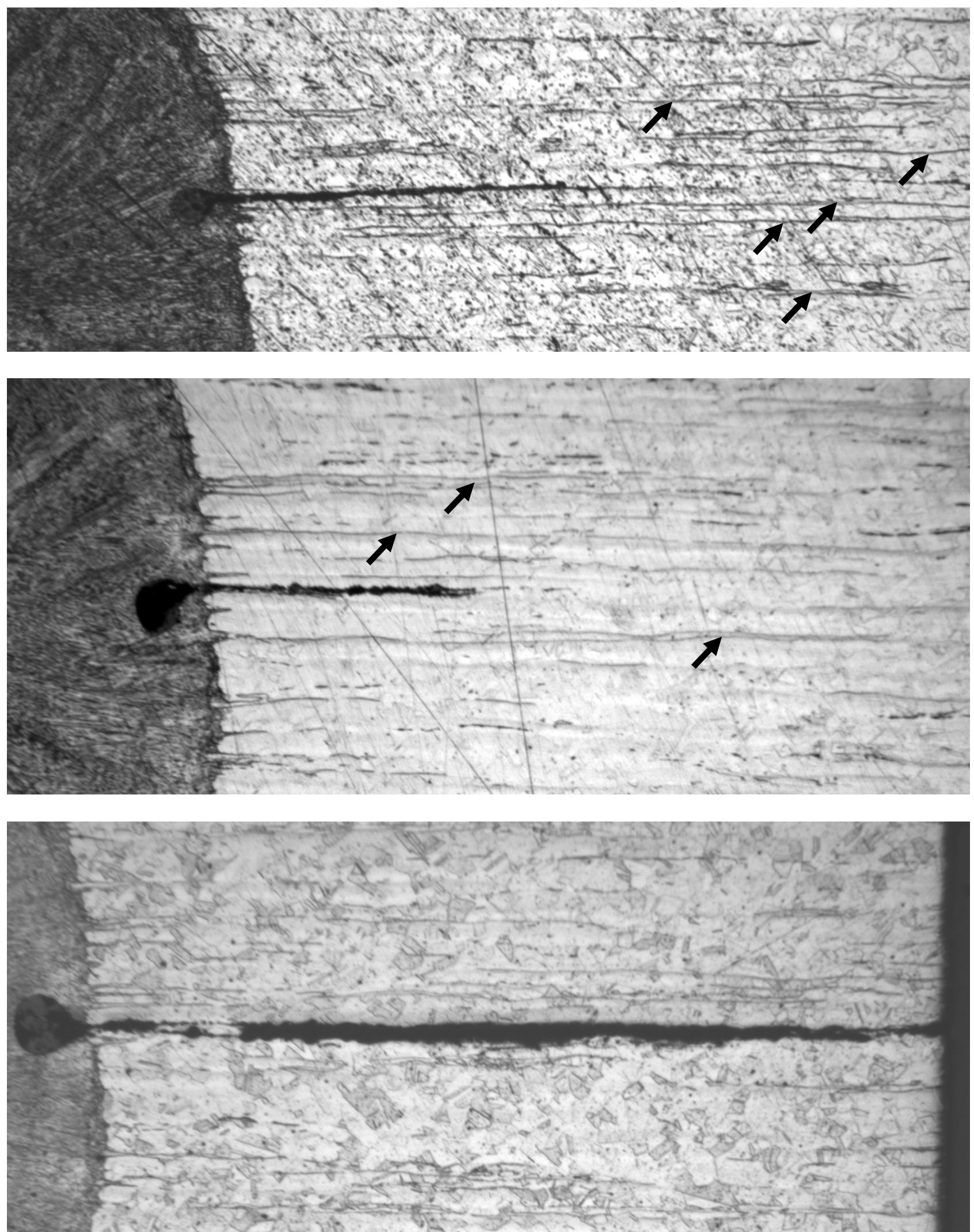

Figure 11. Detail of leak path from the last 3 sections shown in Figure 10. Some of the stringers not associated with the leak path are highlighted (arrows). 


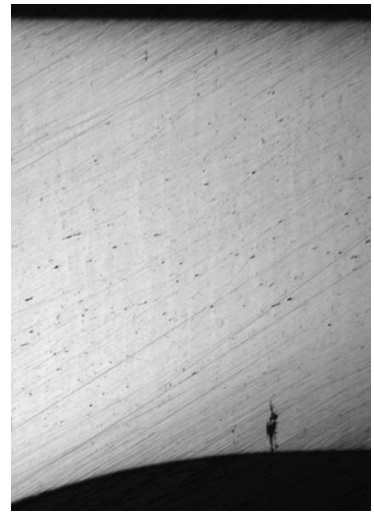

(a)

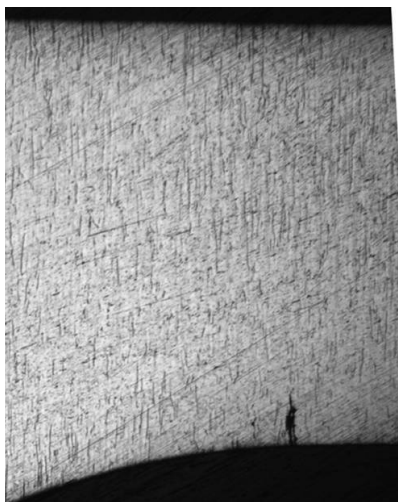

(b) 0.006 inch

deeper than (a)

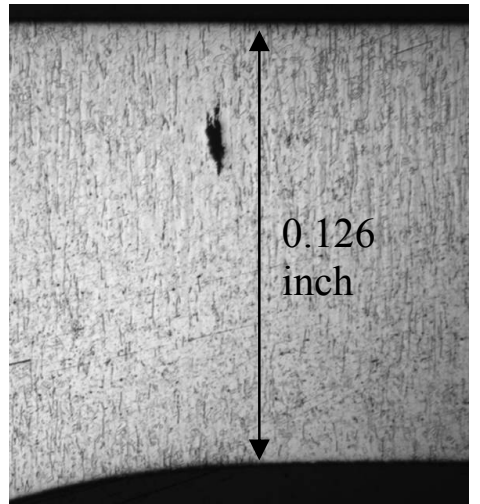

(c) 0.0075 inch deeper than (b)

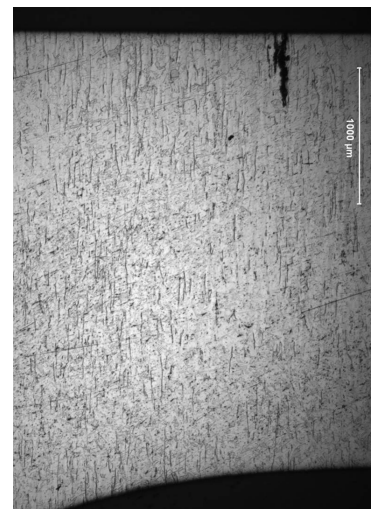

(d) 0.004 inch deeper than (c)

Figure 12. Series of metallographic cross sections through one of the weld-repaired locations in Cap 9. Section thickness at leak $=0.126$ inch.

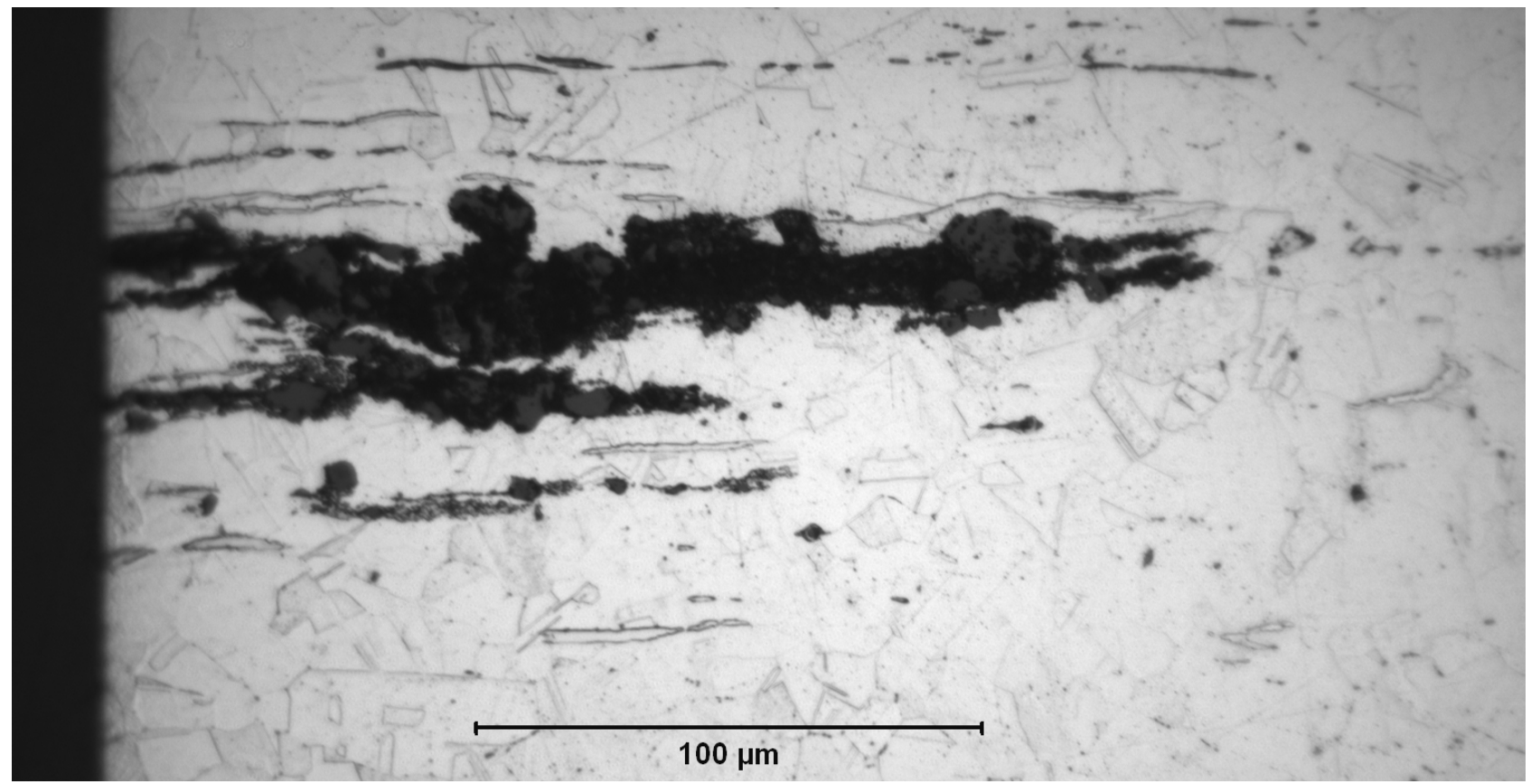

Figure 13. Detail of leak path from the last section shown in Figure 12. 


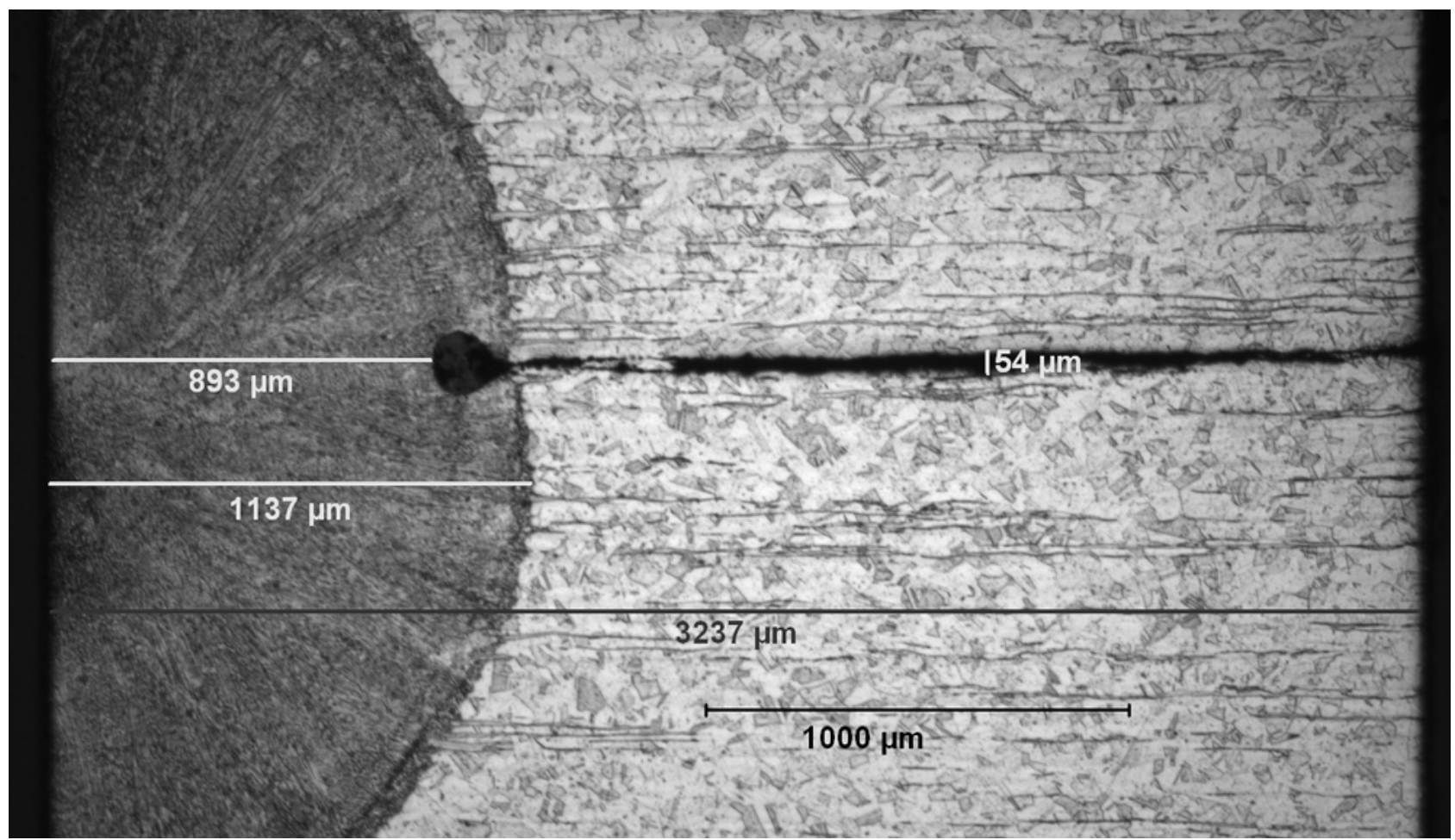

Figure 14. Measurement of inclusion features from leak path shown in Figure 10.

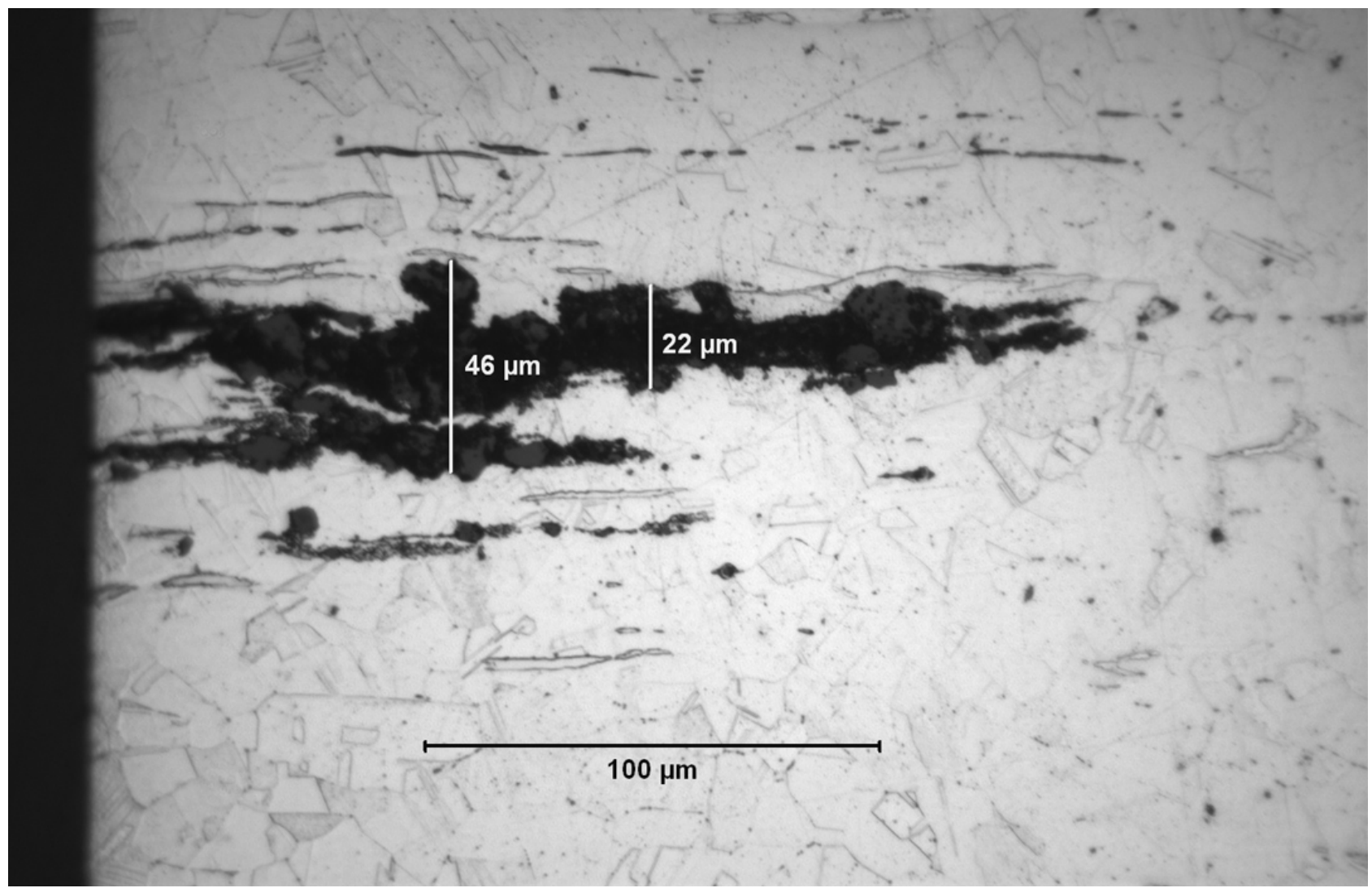

Figure 15. Measurement of inclusion features from leak path shown in Figure 12. 

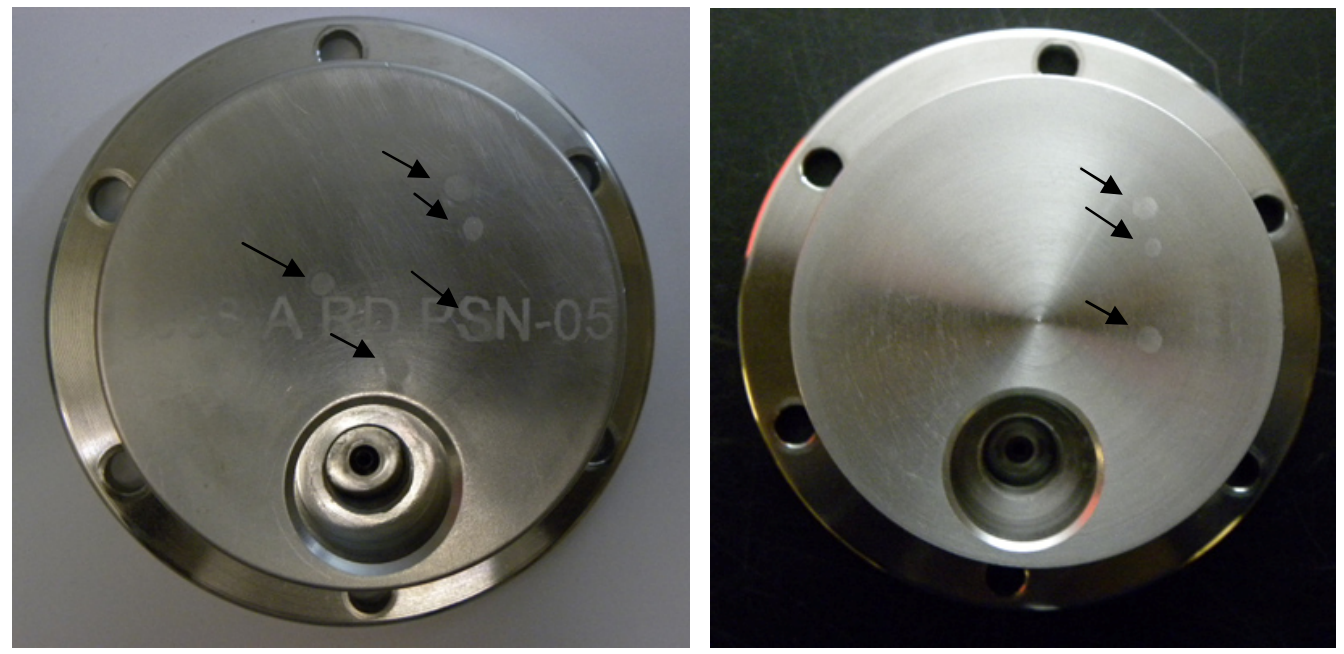

Figure 16. Protective cap number 5, after etching to reveal repair weld locations (at arrows). After machining 0.010 inch from the top surface, two of the five repair welds had been removed.
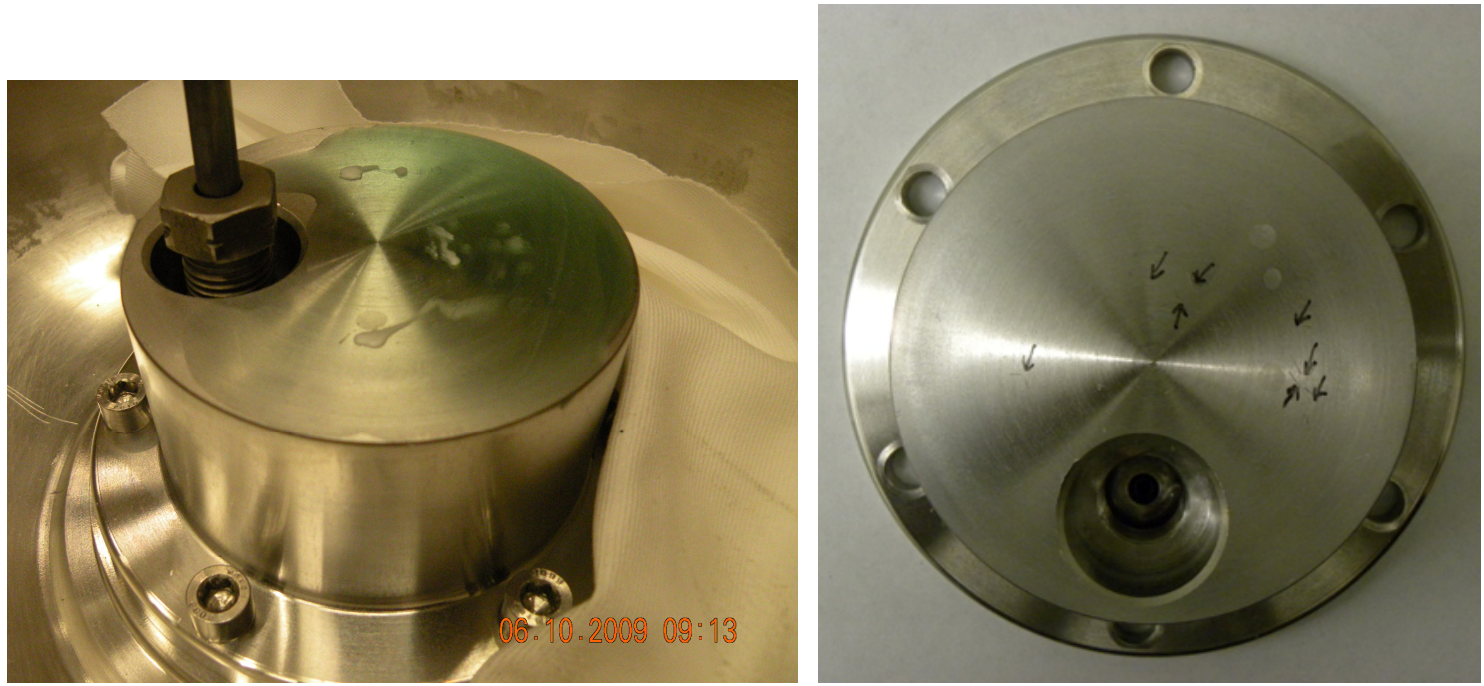

Figure 17. Leak locations identified in cap 5 after machining 0.010 inch from the top surface (arrows). Note that none of these locations correspond to the original weld repair locations seen in Figure 16. 
CC: J. S. Bellamy, 773-41A

P. S. Blanton, 773-41A

G. T. Chandler, 773-A

W. L. Daugherty, 773-A

K. R. Eberl, 773-41A

N. C. Iyer, 773-41A

P. S. Korinko, 773-A

J. L. Murphy, 773-41A

Document Control 